\title{
STUDIES ON NEW DIGENEAN TREMATODE OF THE GENUS ORIENTOCREADIUM TUBANGI, 1931 PARASITIZING FRESH WATER FISH, CHANNA PUNCTATA (BLOCH.)
}

\author{
Dhanraj Balbhim Bhure $^{1 *}$, Sanjay Shamrao Nanware ${ }^{1}$ and D.M. Pathan ${ }^{2}$ \\ ${ }^{1}$ Post Graduate Department of Zoology, Yeshwant Mahavidyalaya, Nanded (M.S.). \\ ${ }^{2}$ Department of Zoology, Shrikrishna Mahavidyalaya, Gunjoti Dist. Osmanabad (M.S.).
}

\section{Review Paper}

Received: 05.11.2021

Revised: 15.11.2021

Accepted: 25.11.2021

\begin{abstract}
Trematode infections occur worldwide. Trematodes, also called flukes, cause various clinical infections in humans. The parasites are so named because of their conspicuous suckers, the organs of attachment (trematos means "pierced with holes").

The present research deals with the detailed description and study of new species Orientocreadium punctatum Sp. Nov. found in the stomach and intestine of Channa punctata (Bloch) from Aurangabad, Osmanabad, Ahmednagar district of M.S. India during Feb., 2005 - Jan., 2007. The present species is comes closer to all the known species of the genus Orientocreadium $^{3}$ in having general topography of organs but differs due to elongated, and non-spinose body, sub terminal and spherical oral sucker, Ventral sucker rounded, Pre- pharynx absent, Pharynx muscular, oval, Oesophagus short, genital pore pre-acetabular, testes unequal, post-ovarian, cirrus pouch crescent shaped, ovary oval, pre-testicular, large, behind oral sucker, receptaculum seminis absent, eggs elongated, oval and non-operculated.
\end{abstract}

Keywords: Channa punctata, Orientocreadium punctatum, Taxonomic Studies, Trematodes.

\section{INTRODUCTION}

Fishes are important due to its nutritional, medicinal and economical value. Fishes are good source of quality protein (Prakash et al, 2021a,), but various diseases including parasitic infections pose a threat to fish health (Peddinti et al., 2021; Narayan et al., 2021). Diseases affect the normal health conditions and cause reduction of growth, abnormal metabolic activities and even death (Prakash, 2021). In India freshwater productivity especially inland culture fishery decreases due to various parasites which causes death of culturable fishes (Prakash et al., 2021b). Since these pathogens affect the reproductive potential of host fishes, a parasitic disease reduces the fish production, profitability, and market as well as nutritive value (Prakash and Singh, 2020). The parasites may cause mortality and morbidity in cultivable fishes resulting in great loss in fish production as well as economic loss to be culturists (Prakash and Verma, 2017).

Parasitic diseases are the limiting factors in fish culture, because of increased density of fish in lentic water bodies where the fish pathogens can easily transmit from one fish to another. These pathogens may cause fish mortality in cultural fishes where the entire fish population of water body may be killed, resulting the great economic loss of fish farmers (Prakash and Verma, 2020). Thus, parasites of fish are one of the major problems to fish health and a number of literatures are available regarding population

*Corresponding author: drajbhure82@gmail.com 
dynamics of helminth parasites across the globe (Verma et al., 2006, 2007). These helmitnths are acoelomates with triploblastic and flattened body (Verma, 2017; Verma and Prakash, 2020). Several reports reveal that consumption of undercooked fishes serve as potent source of infection to humans and they are widely distributed across the world. These parasites attack the fish and causes great loss of skin and gill epithelium. Even moderate infection of these parasites may cause a fatal disease, since the infected fish lose its appetite and stop feeding (Meyer, 1991).

Fishes are infected with helminth parasites, results loss of reproductive capacity. Hence the study of helminth parasites is therefore an urgent necessity today. The genus Orientocreadium is erected by Tubangui (1931) with its type species Orientocreadium batrachoides from Clarias batrachus from Philippines. Later on $O$. pseudobagri; O. ottoi; O. elegans ; O. batrachoides redescribed by Bhure and Nanware (2011); O. lucknowensis were added in this genus. This paper is an approach to add on to the sparse knowledge of Orientocreadium Tubangui, 1931 of fresh water fishes from Maharashtra (India).

\section{MATERIALS AND METHODS}

Four immature and five mature specimens of this form were collected from the stomach and intestine of a fresh water fish, Channa punctata (Bloch) from Aurangabad, Osmanabad, Ahmednagar district of M.S. India during Feb., 2005 - Jan., 2007. These trematodes are preserved in hot 4\% formalin and four specimens are stained with Harris haematoxylin and Borax carmine, passed through various alcoholic grades, cleared in xylene, mounted in D.P.X. and drawings are made with the aid of camera lucida. All measurements are given in millimeters.

\section{RESULT AND DISCUSSION}

The body is elongated, small, non-spinose and measures 3.767 (3.446-4.077) in length and 0.800 (0.631-0.970) in width. The oral sucker is subterminal, spherical, small and measures 0.211 (0.203-0.218) in length and 0.189 (0.184-0.194) in width. The ventral sucker is rounded, larger than oral sucker and measures 0.279 (0.266-0.291) in length and 0.233 (0.194-0.271) in width and lying at $0.728 \mathrm{~mm}$ from anterior extremity. Pre- pharynx is absent. Pharynx muscular, oval, behind the oral suckers and measures 0.080 (0.072-0.087) in length and 0.084 (0.072-0.087) in width. Oesophagus short and measures 0.092(0.087$0.097)$ in length and $0.019(0.014-0.024)$ in width. Intestinal caeca broad, slightly coiled, runs along side of the body and terminate towards hind end of body. Genital pore pre-acetabular, measures 0.048 in diameter and lying at $0.786 \mathrm{~mm}$ from anterior extremity. The excretory pore lies at posterior end of body. Testes are unequal, oval, post-ovarian. Anterior testis is smaller than posterior one, measures 0.155 (0.145-0.165) in length and $0.179(0.169-0.189)$ in width and lies at $1.470 \mathrm{~mm}$ from anterior extremity. Posterior testis measures $0.174(0.145-0.203)$ in length and $0.179(0.155-0.203)$ in width and lies at $1.660 \mathrm{~mm}$ from hind end of body. Cirrus pouch is elongated, crescent shaped, lying in front of ventral suckers and measures 0.509 (0.388-0.631) in length and 0.140 (0.106-0.174) in width and lies at $0.800 \mathrm{~mm}$ from anterior extremity. Cirrus is muscular, tubular, within cirrus pouch, forms vas deferens and measures 0.492(0.485-0.500) in length and 0.014 (0.009-0.019) in width. Vas deferens short tube, bifurcates and forms vasa efferentia and measures 0.092(0.087-0.097) in length and $0.012(0.009-0.014)$ in width. Vasa efferentia are long, runs posteriorly and reaches to testes and measures $0.339(0.242-0.436)$ in length. The ovary is oval, pre-testicular, large, behind oral sucker, it measures $0.279(0.266-0.291)$ in length and 0.203 (0.194- 0.213) in width and lies at $1.203 \mathrm{~mm}$ from anterior extremity. Receptaculum seminis absent. Oviduct arises from the ovary and opens at the ootype.

Vitellaria are follicular, small, extending from ventral sucker to posterior testis. The uterus arises from ootype, lying transversely from posterior border of ventral sucker to hind end of body. The eggs elongated, oval, non-operculated and measures 0.050(0.048$0.051)$ in length and $0.023(0.020-0.025)$ in width.

\section{DISCUSSION}

The present form differs from Orientocreadium batrachoides in having body spinose, oesophagus absent, oral sucker larger than ventral sucker, testes overlapping to each other and collected from Clarias batrachus from Philippines.

Present form differs from $O$. pseudobagri in the presence of Receptaculum seminis.

It differs from O. ottoi Agrawal, 1966 in having body aspinose and extension of vitellaria from anterior level of ovary up to hind end of body. 
It differs from Orientocreadium elegans in having body longer and narrower, suckers and pharynx smaller, has spines on the cirrus and inside the metraterm, ovary in posterior half of the body, cirrus sac that lies on the median line of the body dorsal to the ventral sucker and collected from Pelteobagrus fulvidraco.

Present worm differs from Orientocreadium batrachoides redescribed by Bhure and Nanware, ${ }^{2}$ in having body is elongated, small, spinose, muscular Pharynx, crescent shaped cirrus pouch and follicular vitellaria, Pre pharynx absent, oral sucker smaller, ventral sucker larger, Position of testes side by side and eggs elongated.

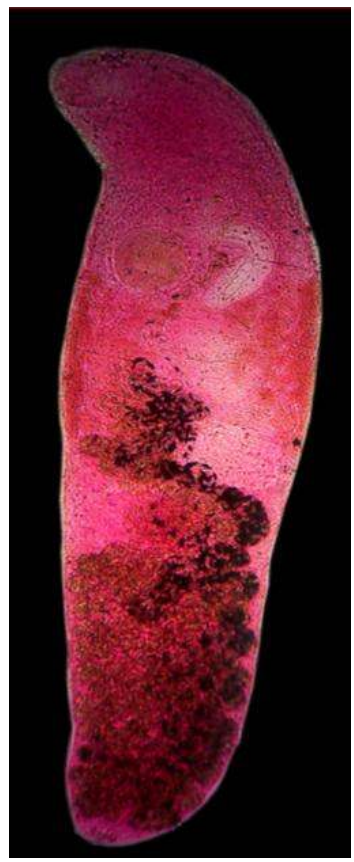

Fig. 1: Microphotoplate of Orientocreadium punctatum Sp. Nov.

\section{Taxonomic Summary}

Genus

- Orientocreadium Tubangui

Species

- Orientocreadium punctatum Sp. Nov.

Type host

- Channa punctata $\{$ Bloch\}

Habitat (Site)

- Stomach, Intestine

Type locality

- Maharashtra (Aurangabad, Osmanabad and Ahmednagar District)

Date of collection

Etymology

- Feb., 2005-Jan., 2007.

- The present species is named after host name Channa punctata
It differs from Orientocreadium lucknowensis in having Oral sucker terminal, Pre-pharynx absent, Pharynx ovoid, Ventral sucker sub-spherical, Ovary spherical and reported from Clarias batrachus at Lucknow U.P.

\section{CONCLUSION}

Thus on account of above mentioned differences as against all those described earlier, the present form deserves the status of a new specific name Orientocreadium punctatum Sp. Nov. The present species is named after host name Channa punctata.

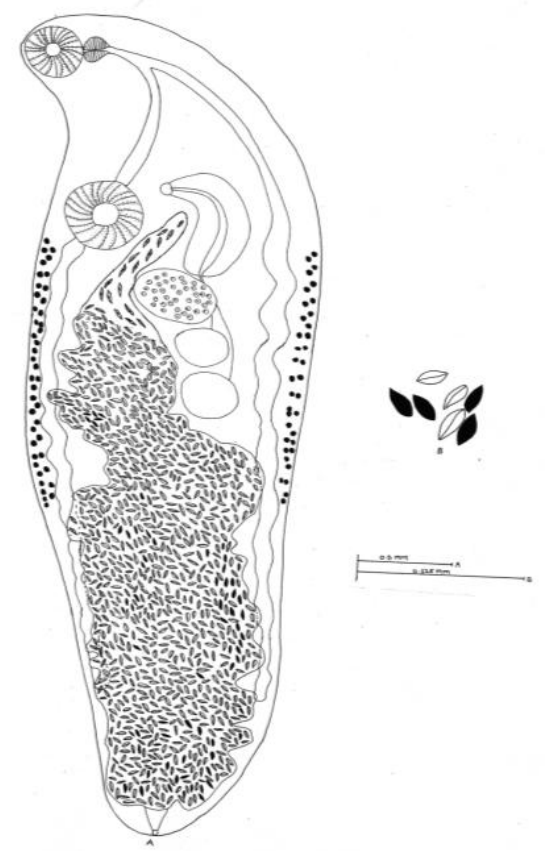

Fig.-2. Camera Lucida sketch of Orientocreadium punctatum Sp. Nov. 


\section{ACKNOWLEDGEMENTS}

The authors are indebted to Principal, Yeshwant Mahavidyalaya Nanded for their kind help, inspiration and providing necessary laboratory facilities.

\section{REFERENCES}

1. Anita Nigam, Satish Chandra, Samta Johri, Saxena A.M. (2015). A New Digenean Trematode of Genus Orientocreadium Tubangui, 1931 Parasitizing Fresh Water Fishes of Uttar Pradesh (India). Helix. 2: 648-65.

2. Bhure D B, Nanware S. S. (2011). Studies on Piscian Trematode Orientocreadium batrachoides from Channa gachua Recent Research in Science and Technology. 3(9): 13-14.

3. Meyer, F.P. (1991). Aquaculture disease and health management. J. Anim. Sci. 69:4201-4208.

4. Narayan A., Yadav R., Singh D. and Rajpoot V. (2021). Prevalence of Piscean cestode, Mystoides chhaviensis in freshwater fish from Bundelkhand region of Uttar Pradesh, India. International Journal of Biological Innovations. 3(2):407-410.

5. Peddinti, R.A., Thummala, C., Khateef, R. and Vankara, A. (2021). Ectoparasitic community ecology of freshwater fishes of River Penna, YSR Kadapa District, Andhra Pradesh, India. International Journal of Biological Innovations. 3(2): 241-256.

6. Prakash, S. (2021). Mycoses infection in some fresh water carps of tarai region of Balrampur. International Journal of Scientific Research in Biological Sciences. 8(1): 1-4.

7. Prakash, S. and Singh, D. (2020).Seasonal variation of helminth Parasites in fresh water fishes of Sauwan Nallah of Balrampur, U.P., India. International Journal of Scientific Research in Biological Sciences. 7(4): 26-29.

8. Prakash, S. and Verma, A.K. (2017). Incidence of parasites in Labeo rohita (Hamiliton) at Balrampur (U.P.). Life Science Bulletin. 14(2): 181-183.

9. Prakash, S. and Verma, A.K. (2020). Seasonal variation in prevalence of ectoparasitic infection in Indian major carps at Balrampur, U.P., India. Uttar Pradesh Journal of Zoology. 41(10):121-127.
10. Prakash, S., Yadav, D.K. and Jaiswal, L. (2021a). Population dynamics of crustacean parasites of fresh water fishes at Bahraich, U.P. International Journal of Zoology and Applies Biosciences 6(1):15-18.

11. Prakash, S., Yadav, D.K. and Jaiswal, L. (2021b). Protozoan parasites of fishes from Chittorgarh reservoir, Balrampur district (U.P.). International Journal of Zoology and Applied Biosciences. 6(6):110-113

12. Tubangi, M. A. (1931). Trematodes parasites of Philippine verebrates. Philipp. J. Sci. 36: 251- 271.

13. Verma A.K., Singh A.K. and Srivastava V.C. (2006). A New Hymenolepid cestode, Podicipitilepis yamagutii N. sp. from the Nightingale, Eudynamis scolopaceus. Flora and Fauna. 12 (1): 111-113.

14. Verma A.K., Singh A.K. and Srivastava V.C. (2007). On a New Hymenolepid cestode, Coronacanthus ashoki N. sp. from the Mole, Crocidura murianus (Linn). Flora and Fauna. 13 (1): 148-150.

15. Verma, A.K. (2017). A Handbook of Zoology. Shri Balaji Publications, Muzaffarnagar. 5th edn. 648p.

16. Verma, A.K. and Prakash, S. (2020). Status of Animal Phyla in different Kingdom Systems of Biological Classification. International Journal of Biological Innovations. 2 (2): 149-154.

17. Vladimir V., Besproz Vannykh, Alexey V, Ermolenko \& Marty R Deveney (2009):. Orientocreadium elegans n. sp. and Orientocreadium pseudobagri Yamaguti (Digenea: Orientocreadiidae), from freshwater fish of the Primorsky region (southern fareast, Russia) with a description of their life cycles. Zootaxa. 2176: 22-32.

18. Yamaguti S. (1958). Systema Helminthum. The digenetic trematodes of the vertebrates. Parts I \& II. Inter science Publ., New York. Vol. (1).

19. Yamaguti, S. (1934). Studies on the helminth fauna of Japan. Part 2. Trematodes of fishes, I. Jap. J. Zool. 5: 249-541. 